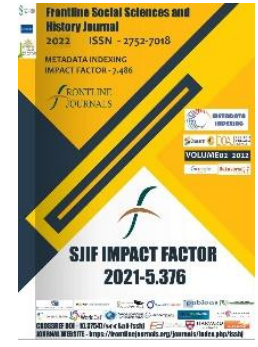

Journal Website: https://frontlinejournal s.org/journals/index.ph p/fsshj

Copyright: Original content from this work may be used under the terms of the creative commons attributes 4.0 licence.
Research Article

\section{ON TEACHING THE GERMAN PHRASEOLOGY IN LITERARY CRITICISM AND TRANSLATION STUDIES}

Submission Date: January 11, 2022, Accepted Date: January 20, 2022,

Published Date: January 31, 2022

Crossref doi: https://doi.org/10.37547/social-fsshj-02-01-08

\section{Gayrat Khafizov}

Lecturer, Department of German Philology, National University of Uzbekistan named after Mirzo Ulugbek, Uzbekistan

\title{
Abstract
}

The science of phraseology is very important in literary criticism, as well as in the deep mastery of German and Uzbek, for the writer, it is one of the most complex areas, which is always needed for a lifetime for a specialist scholar. In particular, the correct use of phraseological words in the translation from German into Uzbek can preserve the idea, art, vitality, nationality of the work and, most importantly, raise the level of literature. In this regard this article discusses the importance of phraseology in the in-depth study of the German language. Therefore, in teaching students the German language in depth, it is important to teach them the basics of phraseology from the very beginning. Given the complexity of the German language, it is important that translators and specialists use phraseology correctly when translating German into Uzbek.

\section{KEYWORDS}

German, phraseology, phraseologism, translation, translator, literary critic, student, linguistics, phrase. 
(ISSN - 2752-7018)

VOLUME 02 ISSUE 01 Pages: 63-68

SJIF IMPACT FACTOR (2021: 5 · 376)

OCLC - 1276789625 METADATA IF - 7.569

\section{INTRODUCTION}

The ability of specialists in the study of German language and literature in general, the study, analysis, comparison and inference of phraseological sentences in both Uzbek and German contributes not only to the deepening of the language, but also to the development of translation and language enrichment.

The science of phraseology is very important in literary criticism, as well as in the deep mastery of German and Uzbek, for the writer, it is one of the most complex areas, which is always needed for a lifetime for a specialist scholar [8]. In particular, the correct use of phraseological words in the translation from German into Uzbek can preserve the idea, art, vitality, nationality of the work and, most importantly, raise the level of literature. In the process of translation, as a result of being able to clearly interpret phraseological words in the study of German, the student, specialist or writer will be able to express their ideas more clearly, broadly and originally, both in writing and in speech. As I.I.Chernysheva said, "... the peculiarity of phraseological words is that as a result of their emergence and preservation and development over the centuries, they are perfectly formed, serve to express the author's opinion, attitude to the event, the emotional state" [11].

Phraseology is also a great way to enjoy aesthetically. It is well known that in fiction, aesthetic perfection and pleasure are the most important means of influencing literature, helping to instill the idea of the work in the mind of the reader. This means that the more accurately the phraseological sentences are translated from German to Uzbek, the more mature the work will be. Also, due to phraseology, the client feels that the events in the work belong to a particular people, their nationality, for example, the German people, their character, customs, culture. When a writer uses phraseological words in a play, he does not, as usual, accurately express a certain fact, event, or object, but expresses it figuratively with phrases and expressions that are preserved on the basis of language. Here, the student's worldview, the level of knowledge is also important, of course, but with the help of expressions specific to folk art, he gradually understands and grasps the essence, the idea of the work. This is because phraseology 
(ISSN - 2752-7018)

VOLUME 02 ISSUE 01 Pages: 63-68

SJIF IMPACT FACTOR (2021: 5 · 376)

OCLC - 1276789625 METADATA IF - 7.569

expresses reality more broadly, not one-sidedly, superficially, but in general, figuratively [6].

\section{MaIN BODY}

According to the Linguistic Encyclopedia Dictionary edited by VN Yartseva, phraseological words or phrases, although composed of semantically related links, "do not obey" the general rules of modern language in terms of syntactic structure and form herewith they are lexically and grammatically formed when expressing an event and has a specific semantic structure [7].

T. Schipman describes phraseology as a single and grand idea consisting of several words while in the "Explanatory Dictionary of Linguistic Terms", phraseological words are interpreted as a lexically inseparable, distinctive, wellstructured, coherent, coherent sentence [9].

Another characteristic of phraseology - it resembles a metaphor, has figurative, emotional colors - is a collection of words. According to VN Telia, phraseology will be based mainly on ancient legends, religious teachings, works of art, folklore. They are the result of some great event in history, and are an abbreviated version of that event. Sometimes, however, they can also appear on the basis of popular phrases, rhymes, jokes, or jokes and remain in the literature [10]. But phraseology is mainly related to historical events, folk customs, holidays, religious ceremonies, teachings and advice of the sages, has been polished for centuries and has become a spiritual heritage that can always be used in literature.

Thus, phraseological competence is part of general linguistic competence. It is an important means of expression that can be understood only by the German people, if translated correctly, and semantically and syntactically in the structure of speech, which, if translated correctly, can be understood by the Uzbek reader, but when translated literally, can lose its meaning. Because of this competence, German-speaking people can easily understand the meaning of a phraseological phrase created by their own people. Therefore, in the study of foreign language phraseology, there may be two views: some consider this field as a secondary tool and not so important, that is, the indollos of thought can be expressed during translation while some believe that in-depth study of this field is possible in-depth study of the culture and history of other peoples, and is important in a broader 
(ISSN - 2752-7018)

VOLUME 02 ISSUE 01 Pages: 63-68

SJIF IMPACT FACTOR (2021: 5 · 376)

OCLC - 1276789625 METADATA IF - 7.569

understanding of their aspirations. This means that the study of a foreign language and its phraseology by a language learner serves as a basis for easy comprehension of this language competence and increases the level of language proficiency [1].

The importance of studying the phraseology of another language is also confirmed by linguists J.M. Arutyunova, T.M. Gurevich, N.A. Krasavsky, E.M. Kargina. They emphasize the role of phraseology in the deep study of a foreign language and in the correct understanding of the culture of another country [3]. In this regard, J.M. Arutyunova and M.K.Borisenko believe that with the help of phraseology, that is, "under the influence of the use of figurative words - a lot of problems of comprehension in the interaction can be solved" [2].

According to N.A. Krasavsky, "Students in the study of a foreign language must study the phraseology of the people of this country" [5]. But unfortunately, universities have little time to study this field.

\section{Conclusion}

It is known that in the current period of rapidity, the types of sciences and subjects in universities have greatly increased. It takes neither time nor energy for a student to master them all perfectly. Therefore, it would be advisable to set aside more hours for the most important subjects, minimizing unnecessary and redundant subjects, considering the student's future specialization.

We also found the following recommendations necessary for students aspiring to become writers, literary critics and translators to become highly qualified professionals:

1) Gradually inculcate in the student's mind the importance and significance of phraseology in literature;

2) To increase the ability to analyze and comprehend the meaning of phrases based on German proverbs and folklore, which is the basis of phraseology in German;

3) To do this, expand the materials of phraseology, give assignments, adequately provide the student with phraseological sentences and sources of different forms and meanings in German. 
(ISSN - 2752-7018)

VOLUME 02 ISSUE 01 Pages: 63-68

SJIF IMPACT FACTOR (2021: 5 · 376)

OCLC - 1276789625 METADATA IF - 7.569

Only then will it be possible for students to acquire a wide range of knowledge in literature and the foreign language being studied. As a result of this method of teaching, the student not only learns the language perfectly. Perhaps, rather than memorizing the language, he knows the essence of the language more deeply on the basis of the affected figurative sentences, or the desire to know increases [4]. This is the most important thing. To do this, it is necessary to continue to provide students with a set of interesting tasks, consisting of separate, additional tasks, so that the student can independently determine the meaning of such phraseological sentences, to form the ability to find sources. Learn to analyze independently, to draw conclusions. Let him consciously understand that it is possible to know the language in depth on the basis of phraseology, to be able to translate it perfectly.

This means that in the process of teaching German, it is necessary to provide the student with exercises with simple lexical and grammatical content in each lesson. Especially when studying sentences related to phraseology, it is important to teach them in groups, a method that helps the student to complete the task easily. For example, in Task 1, if phraseological words related to creatures are taught, while in Task 2, let's say we continue to give phraseologicalspecific assignments related to human behavior, as well as religious holidays, names, customs, art books, the era of knights, Latin, and other topics. As well as, if not only German but also Uzbek phraseology is taught, the student will master the language perfectly by comparison.

\section{REFERENCES}

1. Alikova S.V., Baranova E.V., Shibkova O.S. Phraseologisms in the paradigm of an interdisciplinary approach // Philological Sciences. Questions of theory and practice. Tambov: Gramota, 2016. No. 6 (60): in 3 hours. Part 2. P. 36-38.

2. Kargina E.M. Activation of phraseological units based on reading foreign texts [Electronic resource] // Modern scientific research and innovation. 2015. №3. URL: http://web.snauka.ru/issues/2015/03/5083 7

3. Krasavsky N.A. Selection criteria for phraseological units in teaching students the German language // Foreign languages at school. 2014. No. 1. P. 43-46. 
4. Kunin A.V. Phraseology of modern English. Moscow: International relations, 1972. 288 p.

5. Linguistic encyclopedic dictionary / ch. ed. V.N. Yartseva. Moscow: Bolshaya Ros. Encyclopedia, 2002. 709 p.

6. Ryzhkova A.I. The study of German phraseological units and their use in speech by students of non-linguistic specialties // Philological Sciences. Questions of theory and practice. Tambov: Diploma, 2013. No. 7 (25): in 2 parts. Part I. P. 170-172.

7. Dictionary-reference book of linguistic terms: a guide. 3rd edition, corrected. and additional Moscow: Prosveshenie, 1985. 399 p.

8. Telia VN Russian phraseology. Semantic, pragmatic and linguoculturological aspects. Moscow: Languages of Russian culture, 1996. 288 p.

9. Chernysheva I. I. Phraseology of the modern German language. M.: Higher school, 1970. 199 p.

10. Schippan T. Lexikologie der deutschen Gegenwartssprache. Tübingen: Max Niemeyer Verlag, 2002. 306 p. 